\title{
Trifoliate Orange Seed Germination Enhancing Method in Mid Hill of Nepal
}

\author{
Umesh K Acharya ${ }^{\circledR}$ and Roshan Pakka
}

National Citrus Research Program, Dhankuta, Nepal; @: umeshach@gmail.com, ORCID: http://orcid.org/0000-0001-9197-5010; RK: roshanpakkarp@ gmail.com

Received 5 Jan 2019, Revised 25 Jan 2019, Accepted 25 Feb 2019, Published 28 April 2019

Scientific Editors: Shanta Karki, Ishwori P. Gautam

Copyright (C) 2019 NARC. Permits unrestricted use, distribution and reproduction in any medium provided the original work is properly cited.

The authors declare that there is no conflict of interest.

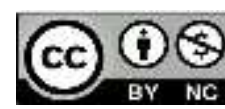

OPEN ACCESS

Licensed under the Creative Commons AttributionNonCommercial 4.0 International (CC BY-NC 4.0)

\begin{abstract}
Trifoliate orange seedlings are used as rootstock for citrus crops due to cold hardiness and phytopthora disease tolerance. Nursery owners usually prepare raised bed in open field to sow seeds of trifoliate. The trifoliate seed production in government farms are very low compared to its demand due to limited number of fruiting trees. Further the germination percent in open nurseries are very low. Hence, production of grafted sapling is very much affected by unavailability of rootstock. Therefore, a study was carried out in National Citrus Research Program, Dhankuta to increase germination rate of trifoliate orange in the year 2016 and 2017. Trifoliate seeds were extracted from three stages of fruits (green mature, half yellow and full yellow) and sown at three dates (September $1^{\text {st }}$ week, September $3^{\text {rd }}$ week and October $1^{\text {st }}$ week) at three raised bed (open field, 50-cm low plastic tunnel with or without sides open). The data on percentage seed germination was taken at 35, 50, 65, 90 and 210 days after seed sowing. The fruit maturity had no effect on germination percentage irrespective of sowing date and method of beds used. The date of sowing resulted significantly higher germination at earlier days but there was non-significant effect during final germination count. Plastic tunnel with open sides resulted $80 \%$ germination compared to $46 \%$ in tunnel side closed nursery. Hence, low plastic tunnel raised bed having open sides is the best option to raise trifoliate seed sown during $1^{\text {st }}$ week of September to $1^{\text {st }}$ week of October in agro-climatic conditions like Dhankuta.
\end{abstract}

Keywords: Citrus, germination percent, maturity, nursery beds, seed

\section{सारांश}

तीनपाते सुन्तलालाई सुन्तला बर्गका फलफूल कलमी गर्न रुटस्टकको रुपमा प्रयोग गरिन्छ। नर्सरी धनीहरुले यसको बिरुवा बीउबाट खल्ला आकाशमा नर्सरी बेड बनाएर तयार गर्छन्। एक त तीनपातेको बीउ कम मात्रामा सरकारी फार्महरुबाट उपलब्ध हुन्छ भने उमार प्रतिशत कम भएकोले भने जति मात्रामा कलमी बिरुवा निकाल्न नसकी रहेको अवस्था छ। तीनपातेको उमार शक्ति कसरी बढाउन सकिन्छ भनेर सन २०१६ र २०१७ मा राष्ट्रिय सुन्तलाजात अनुसन्धान कार्यक्रम, धनकुटामा परिक्षण संचालन गरिएको थियो। यस परिक्षणमा तीनबटा अवस्थाका तीनपाते फलहरु (पर्ण वयस्क हरियो, आधा पाकेको र पर्ण पाकेको) बाट बीउ निकाली तीन वटा मितीमा (सेप्टेम्बर पहिलो, सेप्टेम्बर तेश्रो र अक्टोबर पहिलो हप्ता) तीन प्रकारका नर्सरी बेडहरुमा (खुला जमिन, पू० सेमी उचा प्लास्टिक टनेलको दुई मुख खल्ला र बन्द गरि। बीउ छरिएका थिए। बीउको उमार शक्तिको रेकर्ड बीउ रोपेको ३५, प००, ६५, ९० र २१० दिनमा लिईएको थियो। बिभिन्न पाकेको अवस्थामा रहेका फलको कारण बीउ उमार शक्तिमा कुनै असर नपरेको पाइयो। त्यसै गरि बीउ लगाउने मितीको असर २१० दिन सम्ममा उस्तै पाइयो तर अघिल्ला मितीहरुमा रोपेको बीउमा अघिल्ला दिनहरुमा धेरै उमार शक्ति पाईयो। नर्सरी बेडको बीउ उमार शक्तिमा राम्रोसंग असर परेको देखियो। टनेलको मुख बन्द राख्दा (४६ प्रतिशत) भन्दा खल्ला राख्दा (५० प्रतिशत) बढी बीउको उमार शक्ति पाईयो । धनकुटा जस्तो आवहावा भएको स्थानमा सेप्टेम्बर पहिलो साता देखि अक्टोबर पहिलो सातासम्म टनेल बनाइ मुख खुला राखी तीनपाते सुन्तलाको बीउ रोप्न सुभाब दिईन्छ।

\section{INTRODUCTION}

Quality planting material of citrus crop means budded and grafted plants. Grafted plants require scion of a distinct variety with a compatible and recommended rootstock variety. Citrange and trifoliate oranges are the preferred rootstock varieties in Nepal due to cold and dry hardiness as well as phytopthora disease tolerance (Pun et al 2015). A rootstock for citrus plant is usually of seedling 
origin. The seeds of rootstock varieties (esp. trifoliate orange) are produced in limited quantities (approx. 200kg) by three horticulture farm/stations (Central Horticulture Centre, Kritipur; Horticultural Research Station, Dailekh; and National Citrus Research Program, Dhankuta) in Nepal (NCDP 2016, NCRP 2017). Depending upon geography, the trifoliate fruits mature from September to November in Nepal before the onset of winter season. The seeds are extracted and shade dried for few days (3-5 days) before sowing in open field by the nursery man (Kaini 2003). Usually half to fully ripe (yellow) fruits are harvested to extract seeds. The trifoliate seeds being recalcitrant need to be stored at $4^{\circ} \mathrm{C}$ if not immediately used. The seeds can be stored up to six month with varying degree of viability loss and further affected by fungus if not treated with proper fungicide before storage (Mobayen 1980). Depending upon soil temperature and other climatic factor the seed may require 2535 days to initiate germination (Wiltbank et al 1995) and up to 8 months for full germination (NCRP 2016). Nursery men usually plant seed in raised bed with herb mulch. In horticulture farm/stations seeds are sown in raised bed covered with herb mulch under an arched polythene low tunnel of $50 \mathrm{~cm}$ height. There is an issue of poor germination (around fifty percent) under NCRP farm condition (NCRP 2015). Therefore, a study was designed to find out appropriate harvesting and sowing time of trifoliate seed which could give the best germination rate under different types of nursery beds.

\section{MATERIALS AND METHODS}

To mitigate poor germination problem of trifoliate seed, an experiment was laid out in factorial RCB design with three replications in year 2016/17 at NCRP farm located at an altitude of $1250 \mathrm{~m}$ with geographical location $27^{\circ} 1$ " north latitude and $87^{\circ} 18^{\prime}$ " east longitude. Trifoliate seed extracted from three maturity stages of fruit (green mature, half yellow and full yellow) were sown on four dates $\left(12^{\text {th }}\right.$ August, $20^{\text {th }}$ August, $28^{\text {th }}$ August and $7^{\text {th }}$ September) in three types of nursery beds. In farmers' method, raised bed was prepared, seed were sown without using plastic cover; where as in other two methods: $50 \mathrm{~cm}$ high arched plastic tunnel (200 micron) was established using bamboo with both sides open in Dailekh method and closed in NCRP method. Based on first year's finding, the experiment was repeated in year 2017/18 with four replications comprising same three maturity stages of fruit but with three different dates of sowing $\left(1^{\text {st }}\right.$ week of Sept, $3^{\text {rd }}$ week of Sept and $1^{\text {st }}$ week of Oct) in three type of nursery beds (Farmer's method in Dhankuta, Dailekh and NCRP method). Seeds were sown in 10-m x $0.75-\mathrm{m}$ dimension bed at $10-\mathrm{cm}$ line distance with $3-\mathrm{cm}$ seed to seed distance. The seed beds were prepared one month earlier and covered with plastic mulch for soil solarization (100 micron). During seeding time 30kg vermi-compost was applied to each bed. In each sub-plot, 100 seeds (with seed coat) were sown two $\mathrm{cm}$ deep into soil and mulched with dried herbs (Imerata cylindrical, Cogon grass). The seeds used in this experiment were extracted 6 days before first sowing date, shade dried, treated with $2 \mathrm{~g} / \mathrm{kg}$ Bavistin fungicide and kept refrigerated at $4^{\circ} \mathrm{C}$ until sown. The germination percentage was recorded after seven months in first year trial while it was recorded at 35 , $50,65,90$ and 210 days after sowing (DAS) in second year trial.

\section{RESULTS}

There was no difference on seed germination percent due to maturity stage of fruit on all observation days (Table 1 and 2). However, date of sowing has shown significantly different on germination percent at 35 DAS and 65 DAS with no difference in the result at final count (Table 2). Moreover, types of nursery bed showed significantly different germination percentage on all observation dates except 90 DAS (Table 2) while there was non-significant effect of date of sowing when seeds were sown on $12^{\text {th }}$ August to $7^{\text {th }}$ September in first year (Table 1). Therefore, in second year seed sowing was started from first week of September. Famers could sow seed from any maturity stage fruit from $1^{\text {st }}$ September to $1^{\text {st }}$ week of October provided the seeds are kept in $4-8^{0} \mathrm{C}$ condition treating with Bavistin $(2 \mathrm{~g} / \mathrm{kg})$ if not used immediately after extraction. In case of nursery bed, there was earlier and more germination with NCRP method (tunnel side closed) but seedlings died due to heat stress within one month of sowing and that was not the problem with Dailekh method (tunnel sides open) (Table 2). There was cold injury symptom with farmer's method three months after sowing seed and plastic tunnels were raised to protect the seedlings during the winter season. The highest percentage germination on Farmers' method is due to this reason otherwise Dailekh method is hassle free way of seed sowing. Therefore there is still hope of more than $80 \%$ germination with closing tunnel sides for 
30 DAS and opening the sides till 90 DAS during day time and closing it at night until winter ceases (Table 2).

Table 1. Trifoliate seed germination percentage after seven months of sowing as affected by maturity stage, sowing date and nursery bed structure at NCRP Dhankuta in year 2016/17

\begin{tabular}{lc}
\hline Fruit Maturity & $\begin{array}{l}\text { Germination } \\
\text { \% }\end{array}$ \\
\hline Mature green & 34.69 \\
\hline Half yellow & 41.78 \\
\hline Full yellow & 42.61 \\
\hline Date of Sowing & \\
\hline $12^{\text {th }}$ Aug & 32.81 \\
\hline $20^{\text {th }}$ Aug & 35.70 \\
\hline $28^{\text {th }}$ Aug & 28.78 \\
\hline $7^{\text {th }}$ Sept & 61.48 \\
\hline Nursery Method & \\
\hline Dailekh method & 44.98 \\
\hline Farmer method & 34.96 \\
\hline NCRP method & 39.83 \\
\hline Mean & 39.69 \\
\hline P value (Maturity) & Ns \\
\hline \multicolumn{1}{c}{ (Sowing date) } & $* * *$ \\
\hline$\quad$ Nursery bed) & Ns \\
\hline LSD $(0.05 \%)$ & 10.08 \\
\hline CV\% & 44.01 \\
\hline
\end{tabular}

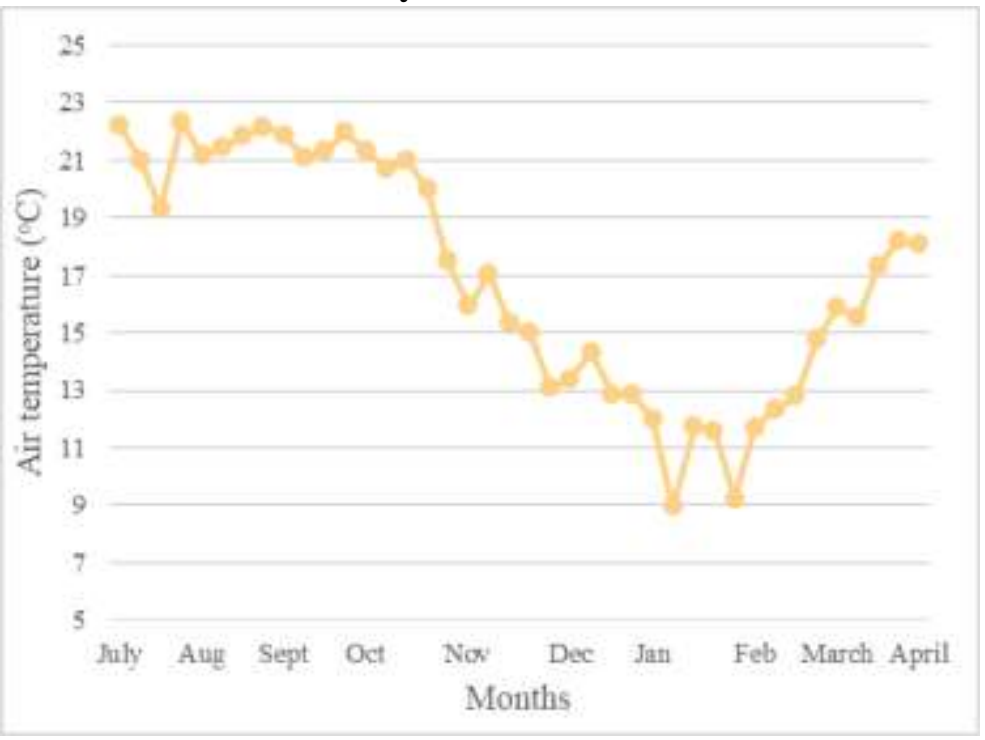

Table 2. Trifoliate seed germination percentage affected by maturity stage, sowing date and nursery bed structure at NCRP Dhankuta in year 2017/18

\begin{tabular}{lccccc}
\hline Fruit Maturity & 35 DAS & 50 DAS & 65 DAS & 90 DAS & 210 DAS \\
\hline Mature green & 25.89 & 33.92 & 32.39 & 38.42 & 64.81 \\
\hline Half yellow & 23.19 & 31.81 & 35.47 & 31.33 & 70.72 \\
\hline Full yellow & 22.89 & 32.17 & 35.03 & 32.12 & 67.28 \\
\hline Date of Sowing & & & & & \\
\hline $1^{\text {st }}$ wk of Sept & 19.86 & 29.78 & 32.36 & 33.14 & 67.69 \\
\hline $3^{\text {rd }}$ wk of Sept & 23.33 & 35.33 & 40.22 & - & 68.75 \\
\hline $1^{\text {st } w k ~ o f ~ O c t ~}$ & 28.78 & 32.78 & 30.31 & 34.78 & 66.36 \\
\hline Nursery Method & & & & & \\
\hline Dailekh & 16.36 & 37.58 & 40.86 & 38.92 & 75.83 \\
\hline Farmer & 20.61 & 31.75 & 33.00 & 33.33 & 80.00 \\
\hline NCRP & 35.00 & 28.56 & 29.03 & 29.62 & 46.97 \\
\hline Mean & 23.99 & 32.63 & 34.30 & 33.96 & 67.60 \\
\hline P value (Maturity) & $\mathrm{Ns}$ & $\mathrm{Ns}$ & $\mathrm{Ns}$ & $\mathrm{Ns}$ & $\mathrm{Ns}$ \\
\hline (Sowing date) & $*$ & $\mathrm{Ns}$ & $*$ & $\mathrm{Ns}$ & $\mathrm{Ns}$ \\
\hline (Nursery bed) & $* * *$ & $*$ & $* *$ & $\mathrm{Ns}$ & $* *$ \\
\hline LSD $(0.05 \%)$ & 6.71 & 7.08 & 7.47 & 9.12 & 7.72 \\
\hline CV\% & 57.81 & 46.37 & 46.58 & 46.62 & 24.41 \\
\hline
\end{tabular}


Seed sowing date: 1 st Oct

Seed sowing date: 1st Sept

Seed sowing date: 3rd Sept

$(2,21.35)=0.23, p=0.799, \omega_{\mathrm{p}}^{2}=-0.05, \mathrm{Cl}_{95 \%}\left[-0.13,0.17(2,21.68)=0.31, p=0.735, \omega_{\mathrm{p}}^{2}=-0.04, \mathrm{Cl}_{95 \%}\left[-0.13,0.17(2,21.82)=0.10, p=0.902, \omega_{\mathrm{p}}^{2}=-0.05, \mathrm{Cl} \mathrm{l}_{95 \%}[-0.11,0.12\right.\right.$
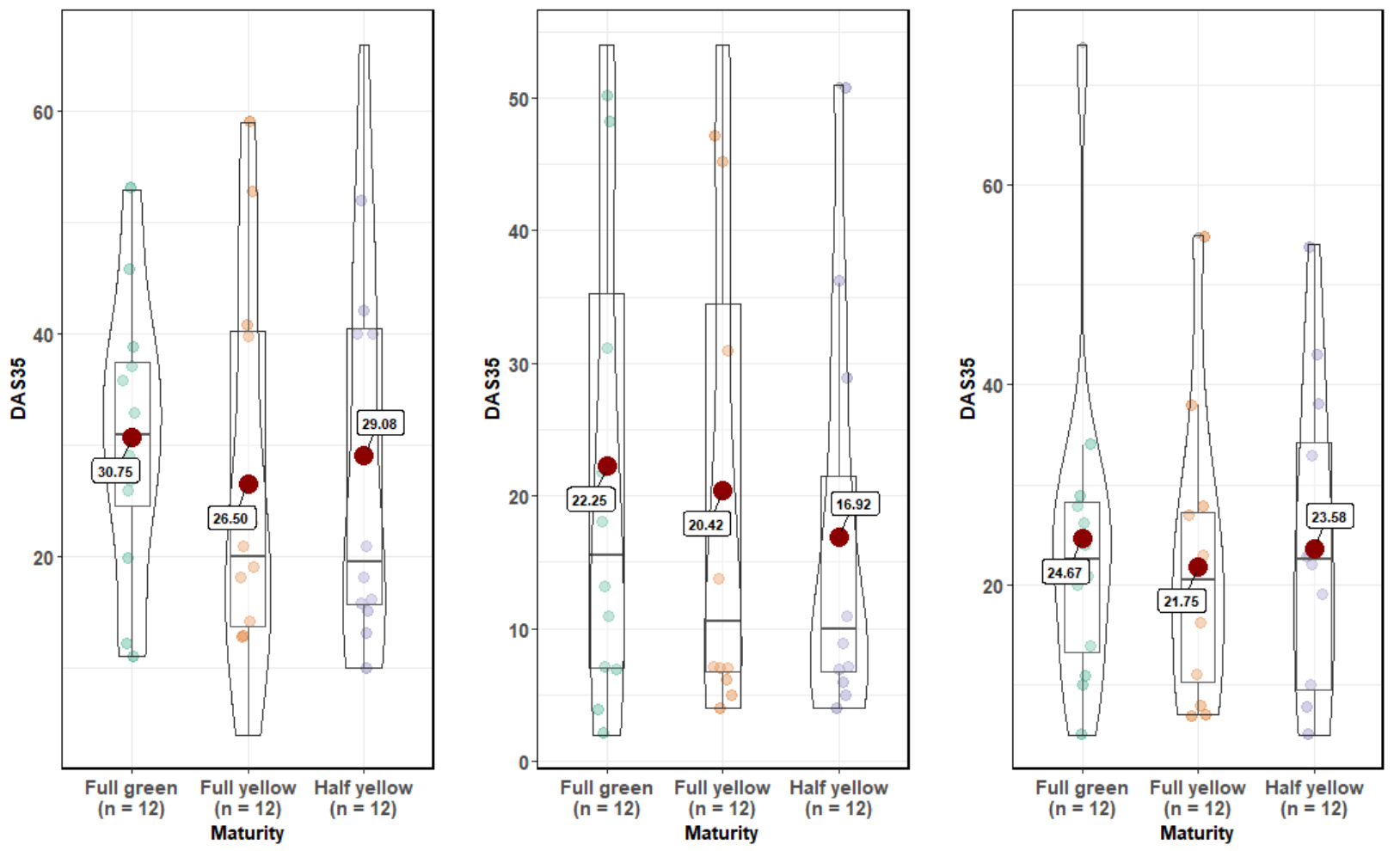

Figure 2. Effect of trifoliate seed sowing date on seed germination at 35 days after seed sowing (the circle value in the middle of boxplot represent mean \% germination)

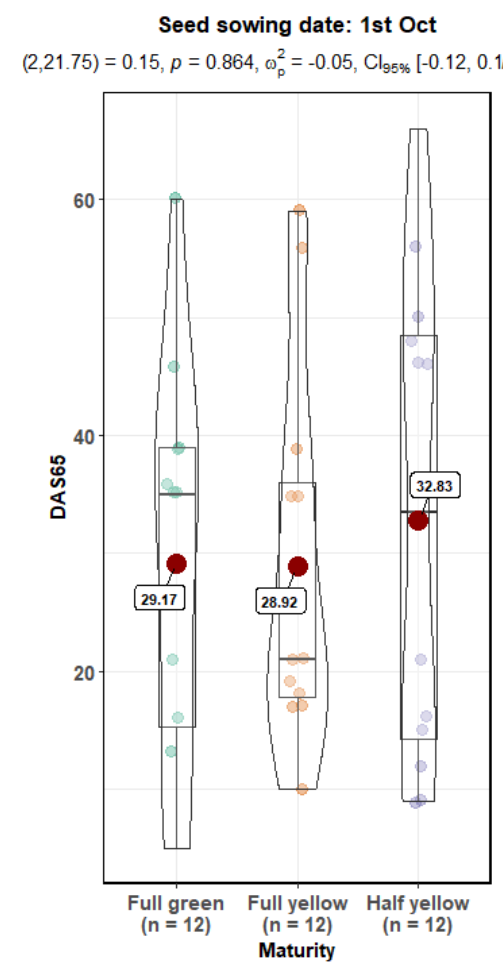

Seed sowing date: 1 st Sept

Seed sowing date: 3 rd Sept

$2,21.75)=0.15, p=0.864, \omega_{\mathrm{p}}^{2}=-0.05, \mathrm{Cl}_{95 \%}\left[-0.12,0.17(2,21.98)=0.07, p=0.934, \omega_{\mathrm{p}}^{2}=-0.05, \mathrm{Cl}_{95 \%}\left[-0.10,0.1 \mathrm{E}(2,21.81)=1.15, p=0.336, \omega_{\mathrm{p}}^{2}=0.01, \mathrm{Cl}_{95 \%}[-0.11,0.23]\right.\right.$

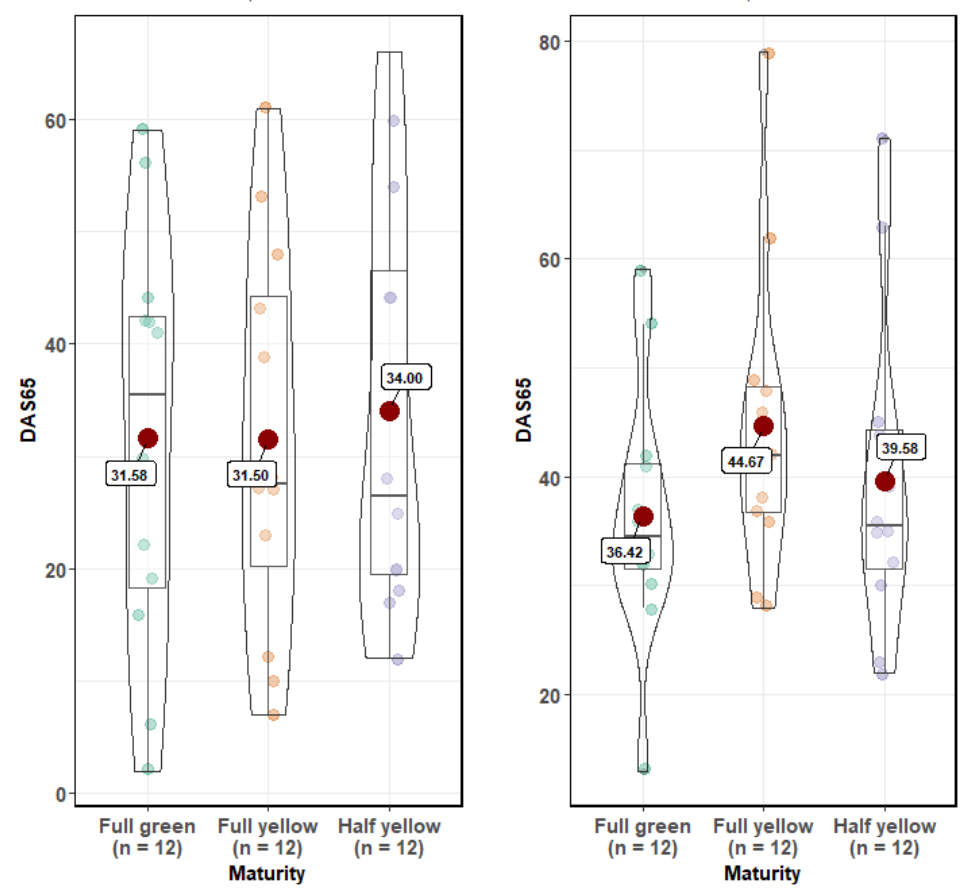

Figure 3. Effect of trifoliate seed sowing date on seed germination at 65 days after seed sowing (the circle value in the middle of boxplot represent mean $\%$ germination). 


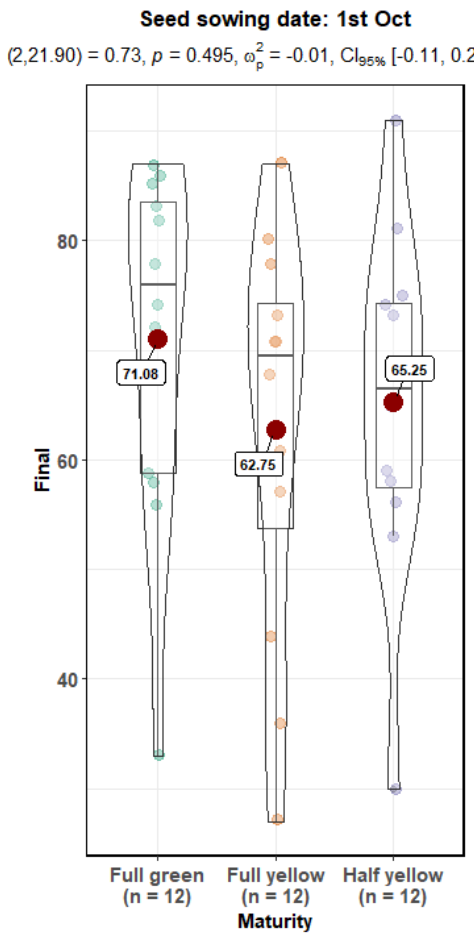

Seed sowing date: 1 st Sept

Seed sowing date: 3 rd Sept

$(2,21.90)=0.73, p=0.495, \omega_{\mathrm{p}}^{2}=-0.01, \mathrm{Cl}_{95 \%}\left[-0.11,0.2 \theta(2,21.77)=0.41, p=0.670, \omega_{\mathrm{p}}^{2}=-0.04, \mathrm{Cl}_{95 \%}\left[-0.11,0.16(2,21.79)=2.38, p=0.116, \omega_{\mathrm{p}}^{2}=0.09, \mathrm{Cl}_{95 \%}[-0.09,0.34\right.\right.$

Figure 4. Effect of trifoliate seed sowing date on seed germination at 210 days after seed sowing (the circle value in the middle of boxplot represent mean \% germination).

\section{DISCUSSION}

All citrus rootstock species germinate within soil temperature range of $15-40^{\circ} \mathrm{C}$ with varying percentage of germination (Camp et al 1933). However, the congenial soil temperature for trifoliate seed germination is between $31-35^{\circ} \mathrm{C}$ (Wiltbank et al 1995) which will likely reach during April to September months in mid hills of Nepal (Figure 1). Further, the trifoliate seed enters into dormancy stage when temperature is $13.9^{\circ}-15.6^{\circ} \mathrm{C}$, which could be the reason for low germination during $65-120$ DAS (Table 2). Nevertheless, storing a September harvested trifoliate seed till March-April under ambient condition has no help as it loses viability very quickly and all citrus nursery owner could not store it between $4-6^{\circ} \mathrm{C}$ during that time (Mobayen 1980). Several researcher reported that $4^{\circ} \mathrm{C}$ higher soil temperature than air temperature inside the low tunnel during mid-day and nearly equal during night (Salman et al 1992, Arin and Ankara 2001, Diaz-Perez 2009). This high temperature could be the reason for newly emerged seedling mortality in sides closed tunnels (NCRP method at 90 DAS) (Table 2). In contrary, it was necessary to raise a tunnel in open field nursery (farmer's method) during December to February (Fig 1) due to temperature below $10^{\circ} \mathrm{C}$ accompanied with frost. This will protect young seedlings in one hand and prevent non germinated seed entering into dormancy, thus increasing seed germination as shown in Table 2.

The seed germination percentage was not significantly affected by the maturity of trifoliate seed irrespective of days of data recording (Figure 2-4). The slower germination rate of trifoliate irrespective of maturity stage during earlier days (12-18 weeks) and final germination percentage (near 80\%) during 24-46 weeks was also reported by (Mobayen 1980). The below $90 \%$ germination percentage of trifoliate seed was also reported by (Saipari et al 1998) and suggested that it is due to hindrance in water imbibition and gas exchange by the seed coat. Removal of seed coat is one way of increasing the seed germination but in commercial scale this is not feasible.

\section{CONCLUSION}

The germination percent of trifoliate seed could be increased with better nursery management practice. Open bed and low tunnel with closed sides are not good practice to follow. A seed from 
mature trifoliate fruit sown during September under plastic tunnels having sides open is recommended to enhance the trifoliate germination under mid hills condition of Nepal.

\section{ACKNOWLEDGMENTS}

The authors would like to thank Nepal Agricultural Research Council for funding support (Project No. 609) to conduct this study.

\section{REFERENCES}

Arin L and S Ankara. 2001. Effect of low-tunnel, mulch and pruning on the yield and earliness of tomato in unheated glasshouse. J. Appl. Hort. 3(1):23-27.

Diaz-Perez JC. 2009. Root zone temperature, plant growth and yield of broccoli [Brassica oleracea (Plenck) var. Italica] as affected by plastic film mulches.Scientia Horticulturae. 123:156-163.

DOI: $10.1016 /$ j.scienta.2009.08.014

Kaini BR. 2003. Package of Practices for Junar production and post-harvest management. JICA- Nepal and JCCU, Kathmandu; First Edition.

Mobayen R. 1980. Germination of trifoliate orange seed in relation to fruit development, storage and drying. Journal of Horticultural Science. 55(3):285-289. DOI:10.1080/00221589.1980.11514936

NCRP. 2015. Annual report 2071-72 (2014-15). Dhankuta: National Citrus Research Program.

NCRP. 2016. Annual report 2072-73 (2015-16). Dhankuta: National Citrus Research Program.

NCDP. 2017. Annual report 2073-74 (2016-17). Kritipur, Kathmadu: National Citrus Dev. Program.

NCRP. 2017. Annual report 2073-74 (2016-17). Dhankuta: National Citrus Research Program.

Pun AB, AR Ansari, MK Thakur and KK Bhandari. 2015. Nepala ma suntalajat falful kheti prabidhi. Nepal Agricultural Research Council, National Citrus Research Program, Dharan; First Edition (In Nepali language).

Saipari E, AM Goswami and M Dadlani. 1998. Effect of seed drying on germination behaviour in citrus. Scientia Horticulturae. 73:185-190. DOI:10.1016/S0304-4238(97)00143-X

Salman SR, AF Abou-Hadid and MS El-Baltagy. 1992. Plastic house microclimate condition as affected by low tunnel and plastic mulch. Egypt J. Hort. 19(2):111-119.

Wiltbank W, RE Rouse and LN Khoi. 1995. Influence of temperature on citrus rootstock seed emergence.Proc. Fla. State Hort. Soc. 108:137-139.

$|1------1|------1 \mid$ 